Heiner C. Bucher ${ }^{1}$, Alfredo Morabia ${ }^{2}$

${ }^{1}$ Medizinische Universitäts-Poliklinik, Kantonsspital Basel

¿ Unité d'épidémiologie clinique, Hôpital cantonal universitaire de Genève

\title{
Teaching physicians about different measures of risk reduction may alter their treatment preference
}

\begin{abstract}
Summary
We explored during a postgraduate workshop whether basic teaching about absolute and relative effect measures changed physicians' perceptions of the benefit to be derived from modifying particular cardiovascular risk factors. Before and after instruction physicians were asked about the priority they would give to interventions to reduce four risk factors of coronary heart disease in two male patients, aged 35 and 65 years with multiple risk factors. They were given information about the relative risk (RR), absolute risk reduction (ARR) and the number of patients who need to be treated (NNT) to prevent one event associated with the modification of each risk factor. Ratings of 48 of the 67 participating physicians $(71.6 \%)$ were evaluated. About half did not change their choices regarding the benefit from a particular intervention. Among those who changed, the new choice was in favor of the patient with the higher ARR for three risk factors (hypertension, $p=0.01$; smoking, $p=0.002$; non-insulin-dependent diabetes, $p=0.05$ ) but not the fourth (left ventricular hypertrophy, $p=0.82$ ). Teaching basic principles of clinical epidemiology to physicians can have an impact on their perception of treatment effects However, this will not suffice in itself to guarantee that this new knowledge will become part of their clinical practice.
\end{abstract}

The results of a clinical trial may be expressed in various ways. For example, $R_{1}$ is the risk for the studied outcome in the treated group and $\mathrm{R}_{0}$ is the risk in the placebo group, it has been shown that physicians are inclined to interpret the results as being more favorable when they are expressed as relative risk $\left(R R=R_{0}: R_{1}\right)$ rather than absolute risk difference $\left(A R R=R_{0}-R_{1}\right)^{1-7}$. The number of patients who need to be treated in order to prevent one event $(\mathrm{NNT})^{8}$ is an additional, very intuitive measure of absolute risk reduction $\left(\mathrm{NNT}=1:\left(\mathrm{R}_{0}-\mathrm{R}_{1}\right)\right)$ that does not yet belong to the interpretation skills of most clinicians.

Basic principles about how to obtain information on RR, ARR and NNT from clinical trials have been published ${ }^{9,10}$ but little is known about whether these principles are used by clinicians. During a postgraduate workshop in continuing medical education we investigated to what extent physicians who have been taught how to compute and interpret RR, ARR and NNT are likely to take these effect measures into account when making treatment decisions.

\section{Methods}

A workshop about basic principles of clinical epidemiology was given during a postgraduate course for continuing medical education offered in 1995 by the Swiss Society of Internal Medicine. The majority of the 67 physicians who attended the workshop were general internists $(51.8 \%)$ and working in private practice $(54.7 \%)$. Of those working in the hospital $(n=28), 67.9 \%$ were residents, $14.3 \%$ were senior residents and $17.9 \%$ were staff members. Mean age was $44.8(\mathrm{SD}=$ 11.2). Mean time since graduation from medical school was 18.4 years $(\mathrm{SD}=11.4)$. Physicians were divided in three one-hour sessions of equal sizes. The language was German in two sessions and French in the other.

Before the lecture, the participants were given a small questionnaire (See appendix) about two male patients aged 35 and 65 years with identical risk factors for coronary 
heart disease: systolic blood pressure of $165 \mathrm{~mm} \mathrm{Hg}$, smoking 15 cigarettes per day, non-insulindependent diabetes and left ventricular hypertrophy on ECG. Using the Framingham risk profile score for incidence of coronary heart disease ${ }^{11}$ we showed for both patients the RR, the corresponding absoute risk reduction and the number needed to treat over 6 years for the following modifications of risk factors: reduction of systolic blood pressure to $120 \mathrm{~mm}$ $\mathrm{Hg}$, cessation of smoking, normalization of glucose intolerance, and normalization of left ventricular hypertrophy. Physicians were asked to rate which of the two patients would benefit most from a given risk factor modification.

After having completed the questionnaire physicians were given 30 minutes instruction given by the two authors. The concepts of risk, RR, ARR and NNT were explained and illustrated with two examples ${ }^{12,13}$. Advantages and disadvantages of these effect measures were explained.

This instruction was followed by a second questionaire (See Appendix) with a slightly different example of two male patients aged 35 and 65 with similar multiple risk factors for coronary heart disease. Again physicians were asked to rate which patient would benefit the most from the following risk factor modifications: reduction of systolic blood pressure from $145 \mathrm{~mm} \mathrm{Hg}$ to normal, smoking cessation in a smoker who consumed 15 cigarettes per day, normalization of blood sugar in noninsulin-dependent diabetes and modification of left ventricular hypertrophy. All three effect measures were similar to those in the first example.

We estimated the impact of our teaching program as follows. For each risk factor modification, the number of physicians who changed their assignment of the higher benefit from intervention in favor of the patient with the higher ARR was compared using the McNemar chi square test with the number of physicians who changed their assignment not in favor of the patient with the higher ARR. Complete questionnaires which allowed paired analysis were obtained from 48 of the physicians. Statistical analysis was done with the SAS package for personal computers $^{14}$.

\section{Results}

Table 1 shows that, after the short instruction, about half of the phy- sicians did not change their assignment of the patient who would benefit most from a given intervention. However, among those who changed, the new choice was in favor of the patient for whom the ARR was higher for three of the four risk factors. For hypertension 18 physicians changed their assignment in favor of the patient with the higher ARR and 5 in favor of another option (higher RR or similar benefit in both patients) $(p=0.01)$. These numbers were, respectively, 22 and 5 for smoking $(\mathrm{p}=0.002) ; 11$ and 9 for left ventricular hypertrophy $(\mathrm{p}=0.82)$, and 16 and 6 for non-insulin-dependent diabetes $(p=0.5)$.

\section{Discussion}

This study suggests that a short period of instruction on basic principles of clinical epidemiology ${ }^{7,9}$ may sensitize some physicians about how to interpret different effect measures and how this information can be integrated into clinical decision making. However, changes in decisions occurred in only half of the physicians, and for another 10 to $20 \%$ the change in preference was not in favor of the patient with the higher ARR.

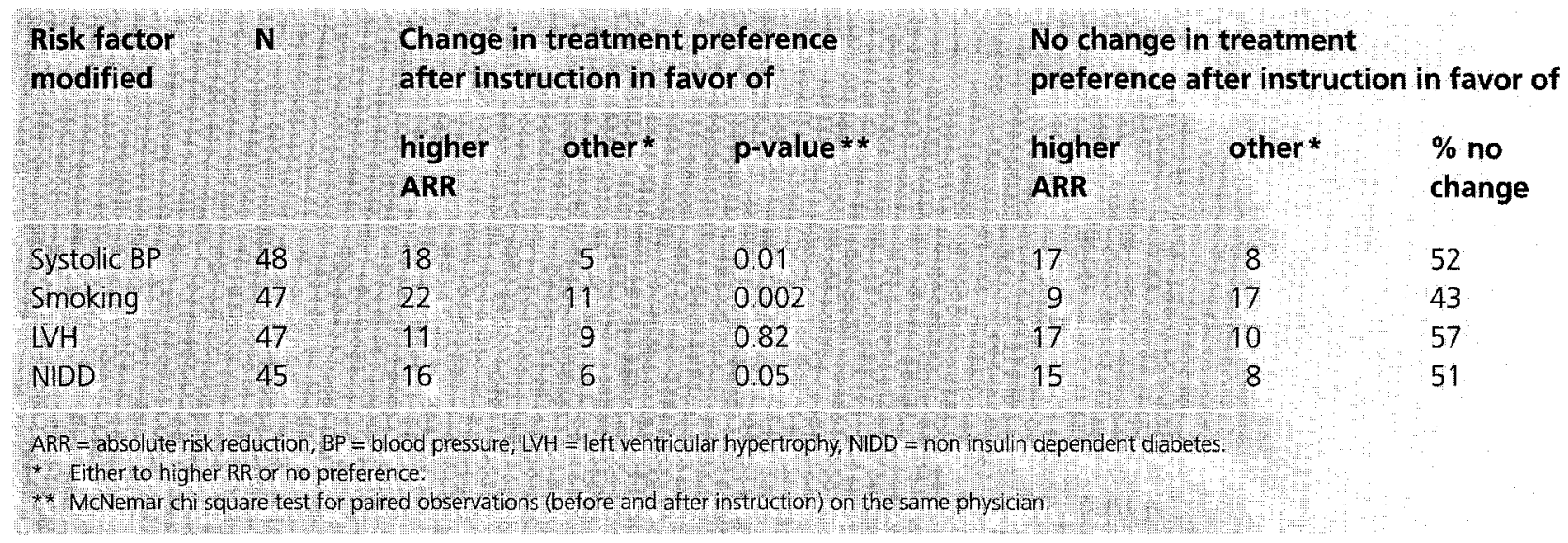

Table 1. Physicians' treatment preference for modifying 4 cardiovascular risk factors prior to and after instruction on basic principles for assessing effect measures. 
Before the instruction, roughly one third of the physicians gave their treatment preference to the patient with the higher ARR from cardiovascular risk factor modification. After the instruction, when two patients with similar multiple risk factors for coronary heart disease were presented, the physicians were more inclined to give treatment to the patient with the higher attributable risk reduction from intervention priority in the case of three of the four presented risk factor modifications. No significant change in treatment preference was found for the treatment of left ventricular hypertrophy. A reason for this finding could be that in the presence of organ damage, and in view of the moderate possibility for its modification, physicians had more difficulty in giving treatment priority to either patient.

Future investigations on the impact of teaching clinicians about epidemiological principles of clinical effect measures could benefit from taking into consideration the limitations of the present study. First, the measure of effects given in the questionnaires were computed using the Framingham risk profile. This model may not be the optimal because it gives six-year risks of coronary heart disease and therefore does not reflect the fact that the remaining life span was higher for the younger subject. In addition, the Framingham risk profile is limited to coronary heart disease and does not consider for any other benefit of smoking cessation.

Secondly, the sample comprised motivated physicians, convinced that attending our workshop would be worthwhile and may therefore not have been representative of the majority of Swiss physicians. Final$1 y$, a short period of instruction may generate confusion in a minority of participants.

In summary, teaching basic principles of clinical epidemiology and evidence based medicine to physicians can have an impact on physicians' perceptions of treatment effects. However, for most of them, this will not suffice in itself to guarantee that this new knowledge will become part of their clinical practice.

\section{Zusammenfassung \\ Information über absolute und relative Risikoreduktion kann Therapieentscheide von ÄrtInnen beeinflussen}

Wir untersuchten in einem Weiterbildungskurs für praktizierende Ärzte, inwiefern die Vermittlung von Grundkenntnissen von relativen und absoluten Wirkgrössen die Beurteilung der Wirksamkeit kardiovaskulärer Risikofaktorenmodifikation verändert. Ärzte gaben vor und nach einem theoretischen Kurs zu 4 Risikofaktoren ihre Behandlungspräferenzen bei je einem 35 - und 65jährigen männlichen Patienten mit multiplen Risikofaktoren an. Fü jede Behandlungssituation lagen die Angaben in relativen und absoluten Risiken sowie die Anzahl zu Behandelnder pro verhütetem Krankheitsereignis vor. Fragebogen von 48 (71,6\%) Teilnehmern $(n=67)$ waren verwertbar. Rund die Hälfte der Teilnehmer änderten in den Angaben nach Kursinstruktion ihre Behandlungspräferenz nicht. Ärzte, welche ihre Behandlungspräferenz änderten, gaben nach Intervention bei drei Risikofaktoren (Hypertonie, $p=0.01$; Rauchen, $p=0.002$, nicht insulinpflichtiger Diabetes mellitus, $p=0.005$ ), jedoch nicht bei der Behandlung der linksventrikulären Hypertrophie $(p=0.82)$ ihre Behandlungspräferenz dem Patienten mit der höheren absoluten Risikoreduktion. Die Vermittlung von Prinzipien der Klinischen Epidemiologie kann die Beurteilung von Behandlungseffekten ändern. Inwieweit dieses Wissen in die praktische Entscheidungsfindung Eingang findet, muss in weiteren Studien evaluiert werden. 


\section{Résumé}

\section{L'enseignement des notions de risque relatif et de risque} attribuable peut influencer la decision therapeutique

Nous avons determiné si l'enseignement de principes elementaires. sur les mesures d'effets absolus et relatifs change la perception par les médedins des bénéfices dune intervention visant a modifier le risque cardio-vasculaire Le plan de recherche était un échantillon non aléatoire de médecins participants a un atelier post-gradué sur des principes élementaires de l'epidemiologie clinique Chaque médecin était son propre temoin. Avant et apres la séance d'enseignement, les medecins indiquaient quelle etait leur oréférence sur une liste d'interventions destinees à reduire 4 facteurs de risque de la maladie coronarienne chez 2 hommes ágés, respectivement, de 35 et 65 ans, ayant de multples facteurs de risque. Risque relatif, risque evitable et nombre de personnes a traiter pour eviter un cas d'infarctus du myocarde étaient indiques en regard de chaque modification de facteurs de risque. Les réponses de 48 des 67 participants $(71.6 \%$ ) ont pu être analysées. Environ $50 \%$ des medecins n'ont pas change de préférence après linstruction. Parmi ceux qui ont change, le nouveau choix était en faveur du patient qui avait le risque evitable le plus éleve pour 3 facteurs de risque (hypertension, $\rho=0.01$, tabagisme, $p=0.002$, diabete noninsulino-dépendent, $p=0.05$ ) mais pas pour le quatrieme (hypertrophie ventriculaire gauche, $\rho=0.82)$. Enseigner les principes de base de l'épldémiologie clinique a des médecin peut avoir un impact sur leur perception des effets d'un traitement. Cependant, ced ne sera pas suffisant pour garantir qu'lis utilisent ces connaissances dans leur pratique.

\section{References}

1 Naylor CD, Chen E, Straus B. Measured enthusiasm: does the method of reporting trial results alter perceptions of therapeutic effectiveness? Ann Intern Med 1992; 117:916-921.

2 Forrow L, Taylor WC, Arnold RM. Absolutely relative: how research results are summarized can affect treatment decisions. Am J Med 1992; 92:121-124.

3 Bobbio M, Demichells B, Glustetto $C$. Completeness of reporting trial results: effect on physicians' willingness to prescribe. Lancet 1994; 343:1209-1211.

4 Bucher $H C$, Weinbacher $M$, Gyr $K$. Influence of method of reporting study results on decision of physicians to prescribe drugs to lower
10 Guyatt GH, Sackett DL, Cook DJ for the Evidence-Based Medicine Working Group. User's guides to the medical literature. II. How to use an article about therapy prevention. B. What were the results and will they help me in carrying for my patients? JAMA 1994; $271: 59-63$.

11 Wilson PWF, Castelli WP, Kannel WB. Coronary risk prediction in adults (The Framingam Heart Study). Am J Cardiol 1987; 59: 91G-94G.

12 Malenka DJ, Baron JA. Cholesterol and coronary heart disease. The importance of patient-specific attributable risk: Arch Intern Med 1988; 148:2247-2252.

13 Hirschel B, Lazzarini A, Chopard $P$, et al. A controlled study of inhaled pentamidine for primary prevention of Pneumocystis carinii pneumonia. N Engl J Med 1991; 324:1079-1083.

14 SAS Institute Inc. SAS/STAT User's Guide, Version 6, Fourth Edition, Volume 1, Cary, NC: SAS Institute Inc. 1989.

\section{Acknowledgement}

The authors would like to thank B. Luong and $\mathrm{Ch}$. Tovena for their assistance during the workshop. 1994; 309:761-764.

5 Sackett DL, Cook RJ. Understanding clinical trials. BMJ 1994; 309: 755-756.

6 Brett AS. Treating hypercholesterolemia. How should practicing physicians interpret the published data for patients? N Engl J Med 1989; 13:764-766.

7 Morabia A. L'épidémiologie clinique. Que sais-je? No3158. Paris: PUF, 1996.

8 Laupacis A, Sackett DL, Roberts $R$. An assessment of clinically useful measures of the consequences of treatment. N Engl J Med 1988; 318:1728-1733.

9 Sackett DL, Haynes RB, Guyatt GH, Tugwell P. Clinical epidemiology. 2nd ed. Boston: Little, Brown, 1991.

\section{Address for correspondence}

Dr. med. H.C. Bucher

Medizinische Universitäts-Poliklinik

Kantonsspital Basel

CH-4031 Basel

Fax +41612654300 


\section{Appendix}

\section{Questionnaire I}

We present the examples of two men having similar risk factors for coronary heart disease. The first man is 35 years old. The second man is 65 years old. Both men have the following risk factors for coronary heart disease: Systolic blood pressure $165 \mathrm{~mm} \mathrm{Hg}$, both men smoke 15 cigarettes a day, have a non-insulin dependent dia- betes and show left ventricular hypertrophy in the ECG.

Using the Framingham risk profile for coronary heart disease we have computed the relative risk, the absolute risk reduction and the number needed to be treated over 6 years associated with modifying each of these risk factors, that is, reduction of systolic blood pres- sure to $120 \mathrm{~mm} \mathrm{Hg}$, smoking cessation, normalisation of glucose intolerance and left ventricular hypertrophy.

For each risk factor indicate in the last column of the table which patient would benefit most from a risk factor modification.

\begin{tabular}{|c|c|c|c|c|c|c|c|}
\hline \multirow[t]{2}{*}{ Risk factor } & \multicolumn{2}{|c|}{$\begin{array}{l}\text { Subject } 1 \\
35 \text { years old }\end{array}$} & \multirow[b]{2}{*}{$\begin{array}{l}\text { number } \\
\text { needed } \\
\text { to treat }\end{array}$} & \multicolumn{2}{|c|}{$\begin{array}{l}\text { Subject } 2 \\
65 \text { years old }\end{array}$} & \multirow[b]{2}{*}{$\begin{array}{l}\text { number } \\
\text { needed } \\
\text { to treat }\end{array}$} & \multirow[t]{2}{*}{$\begin{array}{l}\text { Treat in priority } \\
\text { subject } 1 \text { or } 2\end{array}$} \\
\hline & $\begin{array}{l}\text { relative } \\
\text { risk }\end{array}$ & $\begin{array}{l}\text { absolute } \\
\text { risk } \\
\text { reduction }\end{array}$ & & $\begin{array}{l}\text { relative } \\
\text { risk }\end{array}$ & $\begin{array}{l}\text { absolute } \\
\text { risk } \\
\text { reduction }\end{array}$ & & \\
\hline $\begin{array}{l}\text { Systolic blood } \\
\text { pressure }\end{array}$ & 0.6 & -10 & 100 & 0.6 & -4.1 & 43 & \\
\hline Smoking & 0.6 & -0.8 & 125 & 0.7 & -3.4 & 29 & \\
\hline $\begin{array}{l}\text { Left ventricular } \\
\text { hypertrophy }\end{array}$ & 0.5 & -1.2 & 83 & 0.5 & -5.1 & 20 & \\
\hline $\begin{array}{l}\text { Non-insulin- } \\
\text { dependent diabetes }\end{array}$ & 0.8 & -0.5 & 200 & 0.8 & -2.2 & 45 & \\
\hline
\end{tabular}




\section{Questionnaire II}

We present the examples of two men having similar risk factors for coronary heart disease. The first man is 35 years old. The second man is 65 years old. Both men have the following risk factors for coronary heart disease: Systolic blood pressure $145 \mathrm{mmHg}$, both men smoke 15 cigarettes a day, have a non-insulin dependent diabetes and show left ventricular hypertrophy in the ECG.

Using the Framingham risk profile for coronary heart disease we have computed the relative risk, the absolute risk reduction and the number needed to be treated over 6 years associated with modifying each of these risk factors, that is, reduction of systolic blood pressure to $120 \mathrm{~mm} \mathrm{Hg}$, smoking cessation, normalisation of glucose intolerance and left ventricular hypertrophy.

For each risk factor indicate in the last column of the table which patient would benefit most from a risk factor modification.

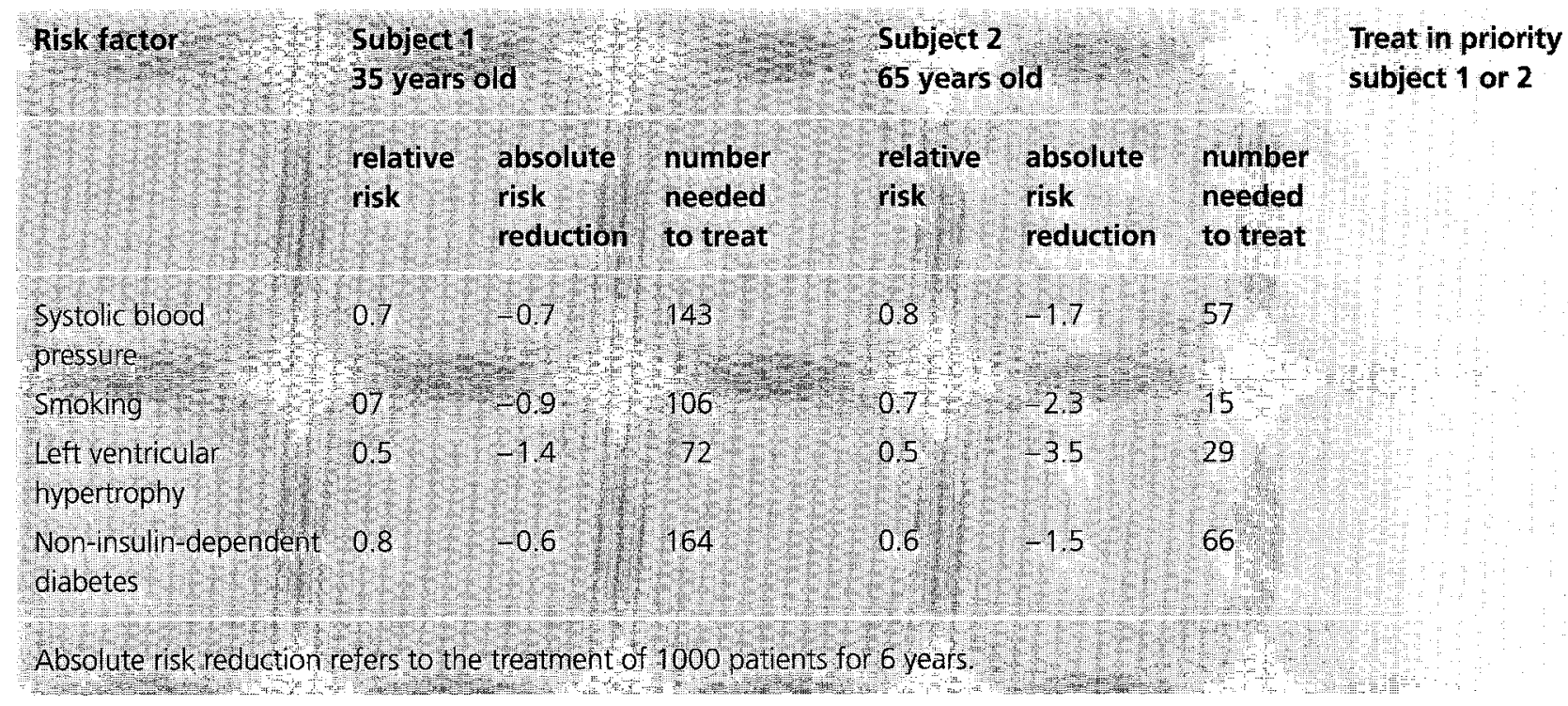

